\title{
Analisis Pengelolaan Wakaf Uang pada Koperasi Jasa Keuangan Syariah (Pendekatan Analytical Network Process)
}

\section{Analisys of Cash Waqf Management on Sharia Financial Service Cooperation (Analytical Network Process Approach)}

\author{
Arie Haura ${ }^{1}$, Lukman M Baga ${ }^{2}$, Hendri Tanjung ${ }^{3}$ \\ ${ }^{1}$ Mahasiswa Sekolah Pascasarjana SB IPB, Email haura.arie@gmail.com \\ ${ }^{2}$ Dosen Sekolah Pascasarjana SB IPB, Email lukmanmb@yahoo.com \\ ${ }^{3}$ Dosen Sekolah Pascasarjana SB IPB, Email hendri.tanjung@gmail.com
}

\begin{abstract}
This study describes the process of Sharia Financial Service Cooperation (KJKS) becoming nazhir waqf, analyzing the priorities of internal and external factors which related with cash waqf. This research uses descriptive quantitative and qualitative approach based on study literature, observation, and quetionaire using analytical network process (ANP) method. The internal factors and external factors devided into 8 cluster. 2 General Cluster and 6 Detailed Cluster: cluster of Internal Aspect, cluster of External Aspect, cluster of SDM KJKS, cluster of Accountability, cluster of Product, cluster of Regulation, cluster of Demography, and cluster of Civil Sociaty. The calculations showed that the highest score which is greatly affect the cash waqf management in KJKS from Internal Aspect such as: Cluster of Accountability (36\%), Cluster of Product (33\%), and Cluster of SDM KJKS (31\%). External Aspect such as: Cluster of Regulation (38\%), cluster of Civil Sociaty (37\%), and cluster of Demography (25\%). Furthermore, the important priority from detailed cluster are Asset Accumulation element $(22,8 \%)$ and Requirement of Sharia Principle $(22,9 \%)$.
\end{abstract}

Keywords : Cash Waqf, Cooperation, Internal Factor, Eksternal Factor, ANP

\begin{abstract}
Abstrak. Penelitian ini memaparkan proses Koperasi Jasa Keuangan Syariah (KJKS) sebagai nazhir wakaf uang, menganalisa prioritas faktor internal dan eksternal terkait. Pendekatan penelitian ini adalah deskriptif kuantitatif dan deskriptif kualitatif berdasarkan studi pustaka, observasi, dan kuesioner dengan menggunakan metode Analytical Network Process (ANP). Metode ANP membagi faktor-faktor internal dan eksternal ke dalam delapan klaster. Dua klaster umum dan enam klaster yang lebih rinci, yaitu Klaster Aspek Internal, Klaster Aspek Eksternal, Klaster SDM KJKS, Klaster Akuntabilitas, Klaster Produk, Klaster Regulasi, Klaster Demografi, dan Klaster Masyarakat Umum. Hasil penelitian menunjukan bahwa prioritas dari Klaster Aspek Internal adalah sebagai berikut: Klaster Akuntabilitas (36\%), Klaster Produk (33\%), dan Klaster SDM KJKS (31\%). Adapun prioritas Klaster Aspek Eksternal adalah Regulasi (38\%), Klaster Masyarakat Umum (37\%) dan Klaster Demografi (25\%). Lebih rinci, prioritas dari faktor internal adalah Jumlah Asset (22,8\%) dan Pedoman Prinsip Syariah (22,9\%).
\end{abstract}

Kata Kunci : Wakaf Uang, Koperasi, Faktor Internal, Faktor Eksternal, ANP

\section{Pendahuluan}

Ekonomi Indonesia disokong oleh tiga pilar yaitu Badan Usaha Milik Negara (BUMN), Badan Usaha Milik Daerah (BUMD), dan Koperasi. Gerakan koperasi di Indonesia sendiri telah dikenal sejak abad 19, yaitu dengan dibentuknya organisasi swadaya (selfhelp organization) untuk menaggulangi kemiskinan di kalangan pegawai dan petani. Gerakan tersebut kemudian dideklarasikan pada 12 Juli 1947 melalui kongres koperasi di Tasikmalaya (Tambunan, 2008).

Tidak seperti badan usaha lainnya, koperasi memiliki ciri khas yang unik yaitu dual identity, anggota sebagai pemilik sekaligus pelanggan. Keanggotaan ini menjadikan 
pengelolaan manajemen koperasi sedikit berbeda dengan badan usaha lainnya karena kesejahteraan anggota yang diutamakan disamping tetap memperhatikan perolehan laba usaha (Maskunah, 2004). Koperasi memiliki peran penting mewujudkan kehidupan demokrasi ekonomi yang mempunyai ciri-ciri demokratis, kebersamaan, kekeluargaan dan keterbukaan (Kementerian Koperasi dan UKM, 2011). Data Kementerian Koperasi dan UKM menunjukan bahwa dewasa ini masyarakat telah memiliki kesadaran untuk berkoperasi yaitu ditandai dengan jumlah koperasi yang terus tumbuh. Seperti dapat dilihat pada Tabel 1.

\section{Tabel 1 Data Koperasi di Indonesia}

\begin{tabular}{rlrr}
\hline No. & \multicolumn{1}{c}{ Provinsi } & $\begin{array}{r}\text { Jumlah } \\
\text { Koperasi } \\
\text { (Unit) }\end{array}$ & Jumlah Anggota \\
\hline $\mathbf{1}$ & Nangroe Aceh Darussalam & 7.428 & 500.202 \\
$\mathbf{2}$ & Sumatera Utara & 12.286 & 2.116 .386 \\
$\mathbf{3}$ & Sumatera Barat & 3.800 & 516.139 \\
$\mathbf{4}$ & Riau & 4.993 & 545.025 \\
$\mathbf{5}$ & Jambi & 3.685 & 367.962 \\
$\mathbf{6}$ & Sumatera Selatan & 5.852 & 630.738 \\
$\mathbf{7}$ & Bengkulu & 2.252 & 176.640 \\
$\mathbf{8}$ & Lampung & 4.833 & 681.948 \\
$\mathbf{9}$ & Bangka Belitung & 1.058 & 106.558 \\
$\mathbf{1 0}$ & Kepulauan Riau & 2.552 & 182.449 \\
$\mathbf{1 1}$ & DKI Jakarta & 7.928 & 879.795 \\
$\mathbf{1 2}$ & Jawa Barat & 25.563 & 5.974 .375 \\
$\mathbf{1 3}$ & Jawa Tengah & 27.784 & 7.042 .617 \\
$\mathbf{1 4}$ & Yogyakarta & 2.610 & 691.575 \\
$\mathbf{1 5}$ & Jawa Timur & 30.850 & 7.522 .356 \\
$\mathbf{1 6}$ & Banten & 6.234 & 919.307 \\
$\mathbf{1 7}$ & Bali & 4.952 & 993.434 \\
$\mathbf{1 8}$ & NTB & 3.966 & 626.117 \\
$\mathbf{1 9}$ & NTT & 3.130 & 698.470 \\
$\mathbf{2 0}$ & Kalimantan Barat & 4.781 & 1.404 .010 \\
$\mathbf{2 1}$ & Kalimantan Tengah & 3.105 & 346.780 \\
$\mathbf{2 2}$ & Kalimantan Selatan & 2.571 & 336.833 \\
$\mathbf{2 3}$ & Kalimantan Timur & 5.184 & 340.076 \\
$\mathbf{2 4}$ & Kalimantan Utara & 735 & 50.284 \\
$\mathbf{2 5}$ & Sulawesi Utara & 6.038 & 422.960 \\
$\mathbf{2 6}$ & Sulawesi Tengah & 2.246 & 267.768 \\
$\mathbf{2 7}$ & Sulawesi Selatan & 8.556 & 1.165 .554 \\
$\mathbf{2 8}$ & Sulawesi Tenggara & 3.368 & 245.538 \\
$\mathbf{2 9}$ & Gorontalo & 1.148 & 135.831 \\
$\mathbf{3 0}$ & Sulawesi Barat & 985 & 173.863 \\
$\mathbf{3 1}$ & Maluku & 3.225 & 71.536 \\
$\mathbf{3 2}$ & Papua & 3.101 & 59.528 \\
$\mathbf{3 3}$ & Maluku Utara & 1.394 & $\mathbf{3 6 . 4 4 3 . 9 5 3}$ \\
$\mathbf{3 4}$ & Papua Barat & 1.595 & \\
\hline & & $\mathbf{2 0 9 . 4 8 8}$ & \\
$\mathbf{S u m}$ & Jumlah & & \\
\hline
\end{tabular}

Sumber: www.depkop.go.id

Saat ini telah berkembang pula koperasi yang berlandaskan prinsip syariah, pada awalnya koperasi syariah ini adalah lembaga baitul maal wat tamwil (BMT). Kemudian karena 
alasan status formal maka operasional pengelolaannya menjadi sama seperti koperasi. Hal tersebut sesuai Keputusan Menteri Negara Koperasi dan UKM No. 91 Tahun 2004 yang mengatur tentang kegiatan usaha Jasa Keuangan Syariah oleh Koperasi.

Selain untuk mendapat ststus formal, alasan lainnya BMT memilih badan hukum sebagai koperasi adalah karena memiliki kesamaan karakteristik bahwa antara BMT dan koperasi diharapkan dapat menjadi perekat para anggota (Sinaga, 2011). Selain itu secara umum mengacu pada prinsip operasional koperasi yang membantu kesejahteraan para anggota dalam bentuk gotong royong maka tentunya prinsip tersebut tidaklah menyimpang dari sudut pandang syariah yaitu prinsip gotong royong (ta'awun ala birri) dan bersifat kolektif (jama'ah) dalam membangun kemandirian hidup (Buchori, 2010).

Hal tersebut juga sejalan dengan tujuan didirikannya BMT yaitu meningkatkan kualitas usaha ekonomi untuk kesejahteraan anggota pada khususnya dan masyarakat pada umumnya. Sehingga orientasi BMT adalah pada peningkatan kesejahteraan anggota dan masyarakat. Anggota harus diberdayakan (empowering) supaya dapat mandiri, masyarakat dapat meningkatkan taraf hidup melalui peningkatan usahanya (Ridwan, 2004).

Sejalan dengan tujuan koperasi yaitu mensejahterakan anggotanya, begitupun dengan Koperasi Jasa Keuangan Syariah. Bahkan lebih dari itu tujuan KJKS adalah untuk mensejahterakan ekonomi kalangan masyarakat yang tidak mampu. KJKS memiliki keunikan yaitu kegiatan Baitul Tamwil dimana tujuan utamanya adalah profit oriented dan kegiatan Baitul Maal yang memiliki konsep kegiatan bukan hanya keuntungan melainkan pemberdayaan dan pengentasan kemiskinan. Dana kelolaan Baitul Maal terdiri dari dana zakat, infaq, shodaqoh, dan wakaf.

Terkait hal tersebut, dalam Program dan Kegiatan Strategis Deputi Bidang Pembiayaan Kementerian Koperasi dan UKM dipaparkan bahwa salah satu program dan kegiatan strategis tahun 2014 adalah menargetkan 100 KJKS di 3 propinsi untuk dapat bekerjasama dengan badan wakaf, program perkuatan kelembagaan KJKS dalam kegiatan maal dan perluasan akses pembiayaan bagi UMKM melalui pendayagunaan wakaf untuk pemberdayaan usaha mikro dan kecil.

Disamping itu tujuan sinergi wakaf dengan KJKS adalah karena KJKS memiliki sumber yang besar untuk dapat digerakan dalam kegiatan wakaf uang. Sumber tersebut adalah potensi anggota KJKS yang bersangkutan. Dalam Hidayat (2014) diungkapkan bahwa peran serta atau partisipasi anggota dapat meningkatkan keberhasilan sebuah KJKS diukur dari meningkatnya kesejahteraan anggota itu sendiri.

Potensi wakaf yang ada di Indonesia sebagai negara dengan mayoritas muslim sangatlah besar. Mustafa Edwin Nasution dalam Syafrudin (2010) memaparkan bahwa potensi wakaf di Indonesia, dengan asumsi bahwa jumlah penduduk Muslim kelas menengah di Indonesia sebanyak 10 juta jiwa dengan rata-rata penghasilan perbulan antara $\mathrm{Rp}$ 500.000,00 (lima ratus ribu rupiah) sampai dengan $\mathrm{Rp} \mathrm{10.000.000,00} \mathrm{(sepuluh} \mathrm{juta}$ rupiah) maka dapat dibuat perhitungan potensi perolehan dana wakaf seperti pada tabel 1 : 
Tabel 2 Potensi Wakaf Uang di Indonesia

\begin{tabular}{lcccc}
\hline $\begin{array}{c}\text { Tingkat } \\
\begin{array}{c}\text { Penghasilan per } \\
\text { Bulan }\end{array}\end{array}$ & $\begin{array}{c}\text { Jumlah } \\
\text { Muslim }\end{array}$ & $\begin{array}{c}\text { Tarif Wakaf } \\
\text { per Bulan }\end{array}$ & $\begin{array}{c}\text { Potensi } \\
\text { Wakaf Tunai } \\
\text { per Bulan }\end{array}$ & $\begin{array}{c}\text { Potensi } \\
\text { Wakaf } \\
\text { Tunai per } \\
\text { Tahun }\end{array}$ \\
\hline 500.000 & 4 juta & 5.000 & $20 \mathrm{M}$ & $240 \mathrm{M}$ \\
1 juta-2 juta & 3 juta & 10.000 & $30 \mathrm{M}$ & $360 \mathrm{M}$ \\
2 juta-5 juta & 2 juta & 50.000 & $100 \mathrm{M}$ & $1,2 \mathrm{~T}$ \\
5 juta-10 juta & 1 juta & 100.000 & $100 \mathrm{M}$ & $1,2 \mathrm{~T}$ \\
\hline \multicolumn{2}{c}{ Total } & & $3 \mathrm{~T}$ \\
\hline
\end{tabular}

Sumber: Mustafa E. Nasution, 2010

Pengelolaan wakaf uang baru berjalan selama dua tahun. Supaya besarnya potensi wakaf uang dapat dikelola dengan baik oleh Koperasi Jasa Keuangan Syariah maka dibutuhkan manajemen yang baik dan tepat. Berdasarkan uraian tersebut maka dirasa perlu dilakukan analisa terhadap faktor-faktor yang terkait dengan pengelolaan wakaf uang di Koperasi Jasa Keuangan Syariah.

\section{Tinjauan Pustaka}

\subsection{Pengertian Koperasi Jasa Keuangan Syariah}

Koperasi Jasa Keuangan Syariah (KJKS) adalah koperasi dengan kegiatan bisnisnya adalah menjalankan proses pembiayaan, investasi, dan simpanan mengikuti pola syariah. Sedangkan Unit Jasa Keuangan Syariah (UJKS) adalah unit bisnis dari koperasi yang menjalankan proses pembiayaan, investasi dan simpanan dibawah prinsip syariah sebagai bagian dari aktifitas bisnis koperasi (Mustofa, 2014).

Dalam Keputusan Menteri Negara Koperasi dan UKM No. 91 Tahun 2004 yang mengatur tentang Kegiatan Usaha Jasa Keuangan Syariah oleh Koperasi. Dijelaskan bahwa melalui peraturan tersebut keberadaan BMT yang semula merupakan lembaga keuangan non formal dapat berubah menjadi lembaga formal berbadan hukum koperasi dengan nama Koperasi Jasa Keuangan Syariah (KJKS).

\subsection{Definisi Wakaf}

Dalam Mundzir Kahf (2007) dijelaskan istilah wakaf menurut bahasa yaitu habs dan waqf untuk kata benda, istilah habasa atau ahbasa dan waqafa atau Auqafa untuk kata kerja. Selain itu tercantum istilah habasa asy-syai' yang berarti: waqafahu la yuba'u wa yuratsi (ditangguhkan, tidak boleh dijual dan tidak boleh diwarisi). Kata al-habs dan al-waqf memiliki arti kata yang sama yaitu karena mengandung makna al-imsak yang berarti menahan, al-man'u yaitu mencegah, dan at-tamakkuts yaitu diam atau menetap. Secara keseluruhan istilah-istilah tersebut mengandung makna yaitu menahan diri dari mengonsumsi, menjual serta mempertahankan sesuatu dari semua perbuautan ini. Selain itu juga berarti menahan dan mencegah manfaat serta keuntungan dari seseorang atau tujuan yang tidak sejalan dengan tujuan pewakafnya. 


\subsection{Wakaf Uang}

Landasan hukum mengenai pengeloaan dana wakaf tunai di Indonesia sudah ditetapkan oleh Komisi Fatwa Majelis Ulama Indonesia yaitu:

1. Wakaf uang (cash wakaf/waqf al-Nuqud) adalah wakaf yang dilakukan seseorang, kelompok orang, lembaga atau badan hukum dalam bentuk uang tunai.

2. Termasuk ke dalam pengertian uang adalah surat-surat berharga.

3. Wakaf uang hukumnya jawaz (boleh).

4. Wakaf uang hanya boleh disalurkan dan digunakan untuk hal-hal yang dibolehkan secara syar'i.

5. Nilai pokok wakaf uang harus dijamin kelestariannya, tidak boleh dijual, dihibahkan, dan atau diwariskan.

Menurut Cizakca dalam Syafrudin (2010) dijelaskan bahwa wakaf tunai pertama kali dipakai pada masa Utsman di Mesir, berkembang pemakaian fikih Hanafi dalam menjalankan bisnis dan sosialnya. Disebutkan pula bahwa Imam Muhammad AsySyaibani menjelaskan bahwa sekalipun tidak ada dukungan hadis yang kuat, penggunaan harta bergerak sebagai wakaf dibolehkan, jika hal itu sudah menjadi kebiasaan umum pada daerah tertentu.

Terdapat tiga alasan mendasar para ahli fikih era Utsmani menyusun bangunan wakaf tunai yaitu Pertama terkait pandangan bahwa aset bergerak dapat menjadi harta wakaf. Kedua, penilaian dan penerimaan atas uang sebagai aset bergerak, Ketiga, Persetujuan atas pemberian uang tunai.

Di era modern ini, menurut M.A. Mannan seperti dijelaskan dalam Nafis (2013) menggagas adanya wakaf uang dengan melalui pembentukan Social Investment Bank Limited (SIBL) di Bangladesh yang dikemas dalam mekanisme instrumen Cash Waqf Certificate. Model ini di anggap sangat tepat untuk mewujudkan kesejahteraan sosial dan membantu merangsang pertumbuhan ekonomi ditingkatan masyarakat bawah.

Wakaf uang sangat relevan memberikan model mutual fund melalui mobilisasi dana abadi yang digarap melalui tangan professional yang amanah dalam fund management-nya ditengah keraguan terhadap pengelolaan dana wakaf serta kecemasan krisis investasi domestik, dan sindrom capital flight. Ia sangat tepat merangsang kembalinya iklim investasi kondusif yang dilatari motivasi emosional teologis berupa niat amal jariyah, di samping pertimbangan hikmah rasional ekonomis kesejahteraan sosial. Ia sangat potensial untuk memberdayakan sektor riil dan memperkuat fundamental perekonomian.

Menurut Mu'allim (2014), terdapat beberapa pendapat ulama yang memperbolehkan wakaf uang yaitu diantaranya:

1. Imam al-Zuhri (w.124 H) menjelaskan bahwa mewakafkan dinar hukumnya boleh, dengan cara menjadikan dinar tersebut sebagai modal usaha kemudian keuntungannya disalurkan pada mauquf' alaih.

2. Para ulama mutaqaddimin (klasik) dari kalangan mazhab Hanafi, membolehkan wakaf uang dinar dan dirham sebagai pengecualian, atas dasar Istihsan bi al-'Urf, berdasarkan atsar dari Abdullah bin Mas'ud r.a: "Apa yang dipandang baik oleh kaum muslimin maka dalam pandangan Allah adalah baik, dan apa yang dipandang buruk oleh kaum muslimin maka dalam pandangan Allah pun buruk".

3. Sebagian ulama mazhab al-Syafi'i: "Abu Tsaur meriwayatkan dari Imam al-Syafi'i tentang kebolehan wakaf dinar dan dirham (uang)". 


\section{Metode Penelitian}

\subsection{Lokasi dan Waktu Penelitian}

Penelitian ini dilakukan di 9 institusi yang berlokasi di Jakarta, Pekalongan, dan Semarang. Rentang waktu yang dibutuhkan dalam penelitian ini adalah selama lima bulan, yaitu untuk proses penyusunan kerangka ANP, penyusunan kuesioner ANP, wawancara dan observasi langsung, pengisian kuesioner serta pengolahan data yang telah dilakukan antara bulan Oktober 2015 sampai dengan Februari 2016.

\subsection{Populasi dan Sampel}

Responden yang dipilih dengan cara purposive sampling, yaitu dengan memilih para responden yang memahami serta terlibat dalam proses pengelolaan wakaf uang di Koperasi Jasa Keuangan Syariah. Responden terdiri dari akademisi, praktisi serta regulator. Secara lebih rinci dapat dilihat pada tabel 2.

Tabel 4 Klasifikasi Data Responden

\begin{tabular}{cll}
\hline No. & Klasifikasi & \multicolumn{1}{c}{ Posisi/Jabatan } \\
\hline 1. & Akademisi 1 & Dosen PSTTI-Universitas Indonesia \\
2. & Akademisi 2 & Dosen FEM-Institut Pertanian Bogor \\
3. & Akademisi 3 & Dosen UIN Syarif Hidayatulah Jakarta \\
4. & Regulator 1 & Direktur Divisi Pembinaan Nazhir-Badan Wakaf Indonesia \\
5. & Regulator 2 & Asisten Deputi Pembiayaan-Kementerian Koperasi\&UKM \\
6. & Regulator 3 & Kepala Subdit Pembinaan Nazhir\&Lembaga Wakaf-Kementeri Agama \\
7. & Praktisi 1 & Manajer Maal KJKS BMT Bahtera-Kota Pekalongan \\
8. & Praktisi 2 & Manajer Maal KJKS BMT An Najah-Kabupaten Pekalongan \\
9. & Praktisi 3 & Manajer Maal KJKS BMT Hudatama-Kota Semarang \\
\hline
\end{tabular}

\subsection{Teknik Pengolahan dan Analisa Data}

ANP merupakan metode dengan pendekatan dimana data yang akan dijadikan sebagai bahan analisis tidak tersedia, sehingga penelitian harus mencari data primer. ANP adalah teori matematis yang memungkinkan seseorang pengambil keputusan menghadapi faktorfaktor yang saling berhubungan (dependent) serta umpan balik (feedback) secara sistematik. Kelebihan metode ini adalah kemampuannya untuk membantu para pengambil keputusan dalam melakukan pengukuran dan sintesis sejumlah faktor-faktor dalam jaringan (Tanjung dan Devy, 2013).

Metode ANP terdiri dari 3 langkah, pertama yaitu dengan pembagian kuisioner dan depth interview ke para akademisi, praktisi, dan regulator untuk mengidentifikasi faktor-faktor yang berpengaruh. Kedua, hasilnya digunakan untuk mengembangkan jaringan ANP yang tepat kemudian untuk penyusunan kuisioner. Ketiga, analisis ANP diaplikasikan untuk membuat alternatif solusi prioritas dan kebijakan strategis (Ascarya, 2005).

Masih menurut Ascarya (2005) dalam Rusdiyana (2013) terdapat tiga prinsip-prinsip dasar ANP yaitu dekomposisi, penilaian komparasi (comparative judgments), dan komposisi hierarkis atau sintesis dari prioritas:

1. Prinsip dekomposisi, yaitu diterapkan untuk menstrukturkan masalah yang kompleks menjadi kerangka hierarki atau kerangka ANP yang terdiri dari jaringjaring cluster. 
2. Prinsip penilaian komparasi, diterapkan untuk membangun pembandingan pasangan (pairwise comparison) dari semua kombinasi elemen-elemen dalam cluster dilihat dari cluster induknya.

3. Prinsip komposisi hierarkis atau sintesis, diterapkan untuk mengalikan prioritas lokal dari elemen-elemen dalam cluster dengan prioritas global dari elemen induk, yang akan menghasilkan prioritas global seluruh hierarki dan menjumlahkannya untuk menghasilkan priorias global untuk elemen level terendah (biasanya merupakan alternatif).

- Geometric Mean

Untuk mengetahui hasil penilaian individu dari para responden dan menentukan hasil pendapat pada satu kelompok dilakukan penilaian dengan menghitung geometric mean (Saaty, 2006). Pertanyaan berupa perbandingan (Pairwisecomparison) dari responden akan dikombinasikan sehingga membentuk suatu konsensus.

- Rater Agreement

Adalah ukuran yang menunjukan tingkat kesesuaian (persetujuan) para responden (R1-Rn) terhadap suatu masalah dalam satu cluster. Adapun alat yang digunakan untuk mengukur rater agreement adalah Kendall's Coefficient of Concordance $(\mathrm{W} ; 0<\mathrm{W} \leq 1) . \mathrm{W}=1$ menunjukan kesesuaian yang sempurna (Ascarya, 2010).

Pengisian kuesioner oleh para responden menggunakan perbandingan skala verbal dan skala numerik. Dalam metode ANP, skala numerik menggunakan rentang angka 1 sampai dengan 9. Data yang diperoleh dari hasil pengisian kuesioner tersebut kemudian diolah menggunakan software "super decision".

Tabel 3 Perbandingan Skala Verbal dan Skala Numerik

\begin{tabular}{lc}
\hline \multicolumn{1}{c}{ SKALA VERBAL } & SKALA NUMERIK \\
\hline Amat sangat lebih besar pengaruhnya & 9 \\
& 8 \\
Sangat lebih besar pengaruhnya & 7 \\
& 6 \\
Lebih besar pengaruhnya & 5 \\
Sedikit lebih besar pengaruhnya & 4 \\
Sama besar pengaruhnya & 3 \\
\hline
\end{tabular}

Sumber: Ascarya (2005)

\section{Hasil dan Pembahasan}

\subsection{Prosedur KJKS Menjadi Nazhir Wakaf Uang}

Pada dasarnya core bisnis utama KJKS adalah adalah jasa pembiayaan. Namun secara karakteristisk karena landasan awal pendiriannya adalah sebagai BMT maka secara umum, KJKS memiliki dua bagian utama yaitu bagian Baitul Maal yang merupakan bagian non-bisnis dimana operasional di dalamnya terkait pengelolaan dana-dana sosial yaitu dana zakat, infak, shodaqoh, dan wakaf. Bagian lainnya adalah Baitut Tamwil, bagian inilah yang merupakan bagian komersil atau bagian bisnis dimana operasional di dalamnya secara umum adalah penghimpunan dana simpanan anggota serta menyalurkannya dalam bentuk pembiayaan. 
Terkait hal tersebut, peneliti juga sepakat dengan pendapat Pristiyanto (2013).

"KJKS memiliki peran strategik dalam perluasan lapangan kerja dan mengurangi kemiskinan. Optimalisasi zakat, infaq, sodaqoh dan wakaf (ziswaf) melalui usaha yang produktif dan berkesinambungan oleh baitul maal KJKS akan bermuara pada pengurangan penduduk miskin. Disinilah KJKS dapat berperan sebagai agent of asset distribution untuk memberdayakan ekonomi masyarakat. KJKS melalui kegiatan baitul maal berfungsi sebagai lembaga sosial dan melalui kegiatan baitul tamwil berfungsi sebagai lembaga bisnis yang profit oriented dengan pola syariah”.

Program Kegiatan Strategis Deputi Pembiayaan Kementerian Koperasi dan UKM tahun 2014 yaitu mengenai penguatan kelembagaan KJKS khususnya dalam kegiatan maal maka KJKS didorong untuk mampu menyerap wakaf uang. Sejauh ini sudah ada lembaga khusus yang menangani wakaf yaitu Badan Wakaf Indonesia (BWI). Oleh karena itu dalam prakteknya KJKS yang hendak menghimpun dan mengelola dana wakaf harus mendapat izin dari pihak BWI. Sehingga dapat disimpulkan bahwa pengelolaan danadana wakaf uang pada KJKS ini merupakan sinergi dari tiga pihak yaitu antara Kementerian Koperasi dan UKM selaku regulator operasional KJKS, kemudian Badan Wakaf indonesia selaku pemberi izin operasional wakaf, dan terakhir adalah KJKS itu sendiri selaku pihak yang melaksanakan kegiatan penghimpunan dan pengelolaan wakaf uang.

Maka dari itu, ada beberapa prosedur yang harus dijalani oleh KJKS untuk mendapatkan sertifikat sebagai nazhir, yaitu:

1. Pertama Kementerian Koperasi dan UKM dalam hal ini selaku regulator melakukan sosialisasi kepada KJKS terkait potensi wakaf uang.

2. Kedua, bagi KJKS yang bersedia menjadi nazhir wakaf uang maka harus mengajukan perizinan kepada Badan Wakaf Indonesia

3. Ketiga, berkas kelengkapan administrasi yang telah dipenuhi oleh KJKS BMT selanjutnya diserahkan oleh Kementerian Koperasi dan UKM kepada pihak Badan Wakaf Indonesia. Selanjutnya lampiran administrasi tersebut dijadikan standar penilaian oleh pihak Kementerian Koperasi dan UKM serta Badan Wakaf Indonesia untuk memutuskan layak atau tidaknya KJKS untuk menjadi nazhir. Selain pihak Kementerian Koperasi dan UKM juga akan memfasilitasi KJKS untuk melakukan paparan business plan.

4. Keempat, berkas KJKS yang telah dinilai oleh BWI dan dinyatakan layak maka selanjutnya KJKS yang bersangkutan akan menerima sertifikat sebagai nazhir wakaf uang.

5. Kelima, proses penghimpunan dan pengelolaan wakaf uang di KJKS harus dilaporkan secara berkala kepada Kementerian Koperasi\&UKM dan juga kepada Badan Wakaf Indonesia. Pelaporan ini diinstruksikan oleh Kementerian Koperasi dan UKM namun dalam penyerahan laporan selain disampaikan ke Kementerian Koperasi dan UKM juga diserahkan ke Badan Wakaf Indonesia.

\subsection{Penentuan Prioritas Faktor Pengelolaan Wakaf Uang di KJKS}

\subsubsection{Penentuan Cluster}

Berdasarkan studi literatur dan hasil wawancara pakar, faktor-faktor yang yang berkaitan dengan pengelolaan wakaf uang di KJKS BMT dibagi menjadi delapan klaster yaitu dua klaster umum yang terdiri dari Klaster Aspek Internal dan Klaster Aspek Eksternal, serta 
enam Klaster Rinci yang terdiri Klaster SDM KJKS, Klaster Akuntabilitas, Klaster Produk, Klaster Regulasi, Klaster Demografi, dan Klaster Masyarakat Umum.

Pada masing-masing klaster terdapat turunan yang disebut dengan elemen. Adapun rincian elemen dari masing-masing klaster adalah sebagai berikut:

1. Klaster Aspek Internal: SDM KJKS, Akuntabilitas, Produk

2. Klaster Aspek Eksternal: Regulasi. Demografi, Masyarakat Umum

3. Klaster SDM KJKS: kemampuan manajerial, pemimpin visioner, misi terukur, sertifikasi, dan partisipasi anggota.

4. Klaster Akuntabilitas: jumlah asset, kinerja keuangan, kelengkapan administrasi, lama beroperasi, dan penunjang fasilitas IT.

5. Klaster Produk: struktur akad, media sosialisasi, jangka waktu, produktifitas pengelolaan wakaf, dan edukasi masyarakat.

6. Klaster Regulasi: pedoman prinsip syariah, standar PSAK wakaf, pembinaan dan pendampingan nazhir, jaminan pengelolaan serta sanksi pelanggaran.

7. Klaster Demografi: yaitu agama, budaya setempat, jumlah penduduk, profesi, dan lembaga pesaing.

8. Klaster Masyarakat Umum: inisiatif pemilik harta, tingkat pendidikan masyarakat, tingkat pemahaman masyarakat, tingkat kepercayaan masyarakat, dan terakhir tingkat keyakinan keberhasilan.

Berdasarkan penentuan klaster-klaster tersebut di atas, maka selanjutnya adalah pembentukan jaringan ANP seperti dapat dilihat lebih jelas pada Gambar 1.

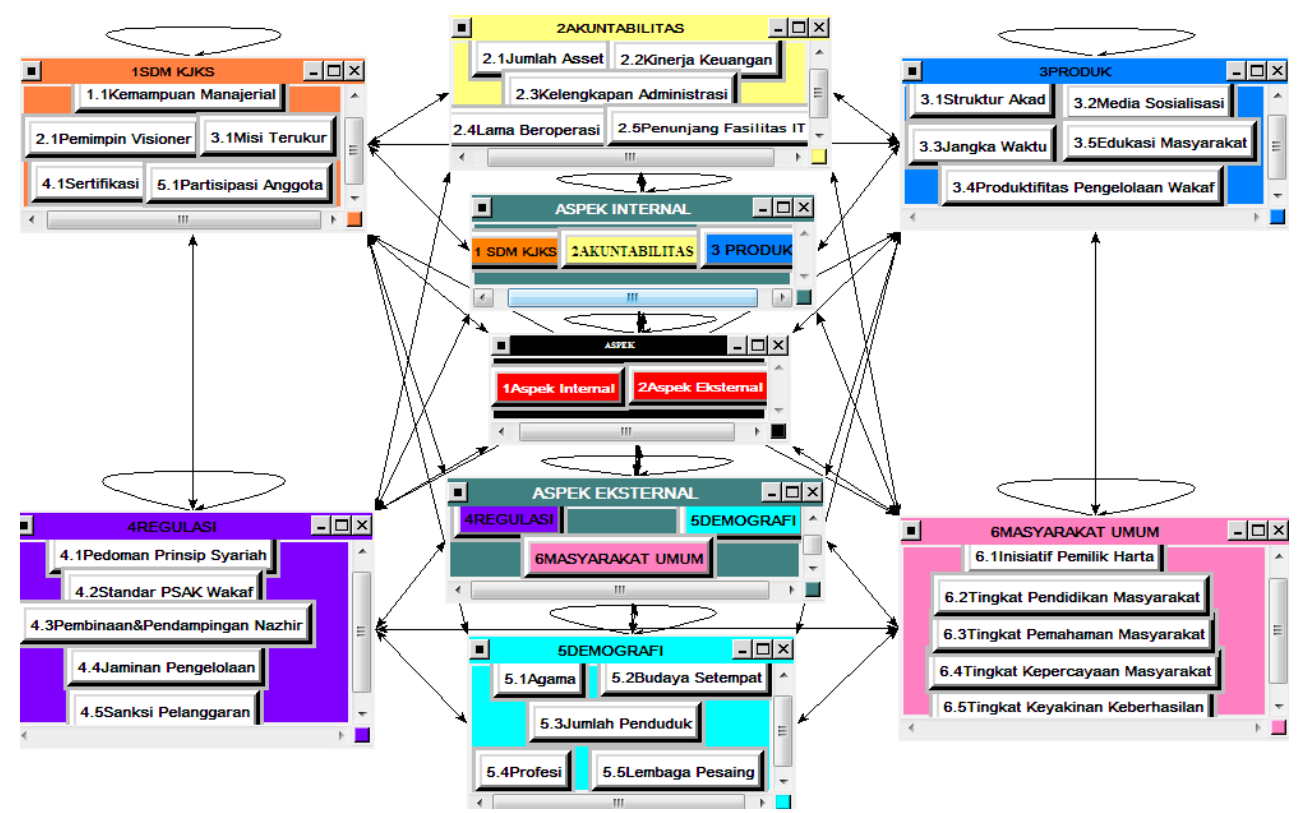

Gambar 1 Jaringan ANP

\subsubsection{Hasil Klaster Umum}

Pihak Akademisi dan Regulator berpendapat sama bahwa elemen SDM KJKS menjadi elemen dengan nilai paling rendah dari dua elemen lainnya, di sisi lain pihak praktisi justru menilai bahwa elemen SDM KJKS merupakan elemen prioritas. Adapun hasil penilaian untuk elemen Produk, pihak praktisi dan akademisi berpendapat sama bahwa dalam pengelolaan wakaf uang elemen produk lebih penting dibandingkan dengan 
elemen akuntabilitas, sedangkan pihak regulator menilai sebaliknya yaitu elemen Akuntabilitas adalah prioritas sebelum elemen produk.

Artinya pihak akademisi menilai bahwa faktor yang paling penting dalam sebuah proses pengelolaan wakaf uang di KJKS adalah pihak SDM itu sendiri sedangkan pihak regulator menilai bahwa justru faktor Akuntabilitas adalah elemen yang lebih penting karena mencerminkan kinerja dari KJKS itu sendiri yang pada akhirnya menjadi tolak ukur kinerja sebuah lembaga keuangan. Kaitannya dengan pengelolaan wakaf tentu saja KJKS dengan akuntabilitas yang baik dinilai akan mampu menjadi pengelola wakaf uang yang amanah kedepannya.

Secara keseluruhan dari hasil penghitungan geomatric mean dari semua responden, didapatkan hasil penilaian bahwa yang paling penting dalam sebuah pengelolaan wakaf uang di Koperasi Jasa Keuangan Syariah pertama adalah elemen Akuntabilitas (36\%), kedua adalah elemen Produk (33\%), dan ketiga adalah elemen SDM KJKS (31\%). Nilai kesesuaian untuk seluruh responden adalah 0,009. Nilai tersebut tergolong rendah dikarenakan pendapat masing-masing responden yang bervariasi. Untuk lebih jelasnya, prioritas aspek internal dapat dilihat pada Gambar 2.

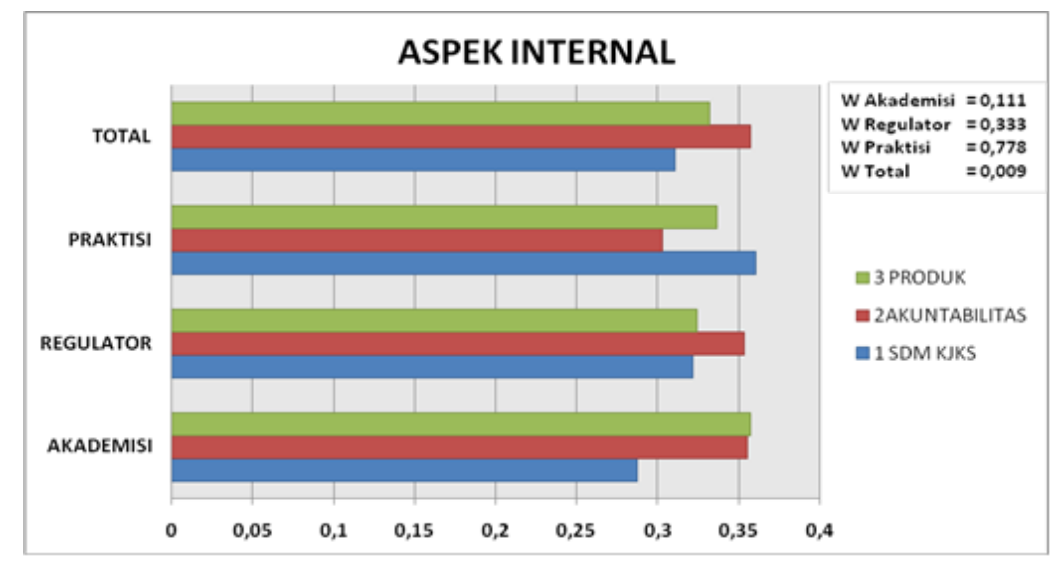

Gambar 2 Prioritas Klaster Aspek Internal

Berikutnya adalah penilaian pada Aspek Eksternal, ketiga responden yaitu baik pihak akademisi, praktisi maupun regulator berpendapat sama yaitu elemen Demografi merupakan elemen dengan skala nilai paling rendah, artinya dapat dikatakan bahwa elemen Demografi merupakan elemen paling tidak berpengaruh terhadap pengelolaan wakaf uang di Koperasi Jasa Keuangan Syariah. Selain itu terdapat persamaan pendapat juga dari pihak akademisi dan pihak praktisi yang menilai bahwa elemen Masyarakat Umum adalah prioritas. Berbeda dengan pihak Regulator yang menilai prioritas adalah elemen Regulasi.

Secara lebih rinci dapat dijelaskan bahwa alasan pihak regulator yang menilai bahwa Regulasi merupakan elemen paling penting karena Regulasi merupakan landasan atau pijakan hukum supaya pengelolaan wakaf di Koperasi Jasa Keuangan Syariah dapat berjalan dengan baik dan terarah. Jadi sebelum pengelolaan dilakukan dan sebelum faktor lain ditentukan maka pijakan hukumm mengenai pengelolaan wakaf itu sendiri harus sudah ada.

Sedangkan dua pihak responden lainnya memiliki pandangan lain yaitu elemen Masyarakat Umum justru merupakan faktor paling penting atau berpengaruh karena bila 
semakin banyak Masyarakat Umum yang dapat diarahkan untuk berwakaf uang terntu akan berbanding lurus dengan besarnya wakaf uang yang dapat dikelola oleh KJKS dan tentu saja akan semakin besar pula manfaat dari wakaf uang itu sendiri bagi si penerima manfaat. Adapun regulasi sifatnya adalah merupakan penunjang untuk keberhasilan pengelolaan waakf itu sendiri.

Secara keseluruhan, diambil rataan (geomean) dari ketiga pihak responden yang menunjukan hasil bahwa elemen prioritas pada cluster Aspek Eksternal pertama adalah Regulasi (38\%), kedua adalah elemen Masyarakat Umum (37\%), dan ketiga adalah elemen Demografi (25\%). Nilai kesesuaian dari seluruh responden (W total) sebesar 0,778 . Nilai tersebut tergolong tinggi dikarenakan jawaban responden yang tidak terlalu bervariatif. Untuk lebih jelasnya uraian penilaian pada Aspek Eksternal dapat dilihat pada Gambar 3.

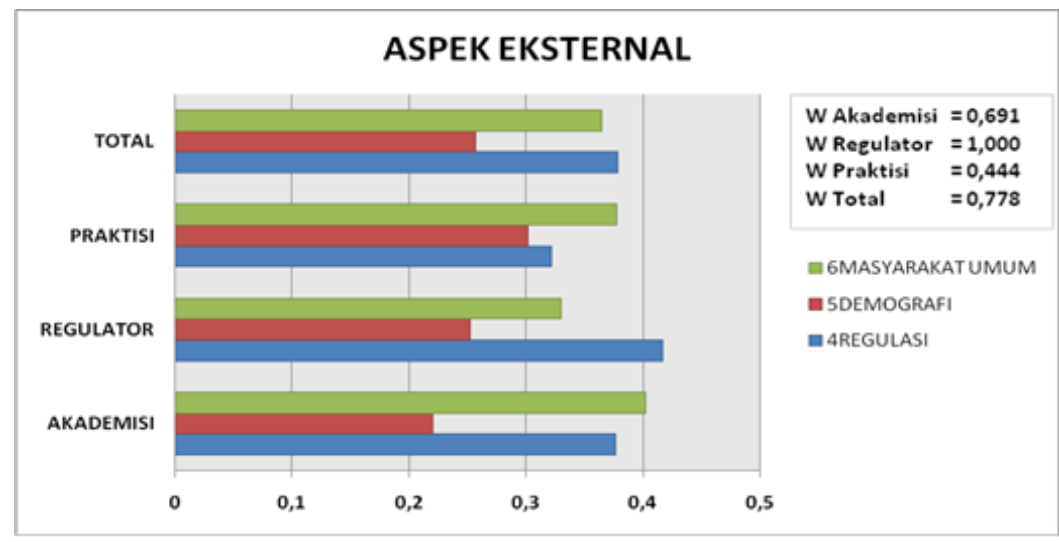

\section{Gambar 3 Prioritas Klaster Aspek Eksternal}

\subsubsection{Hasil Klaster Detil}

Pertama uraian mengenai prioritas elemen dalam klaster Aspek Internal dapat dilihat pada gambar 4. Menjelaskan mengenai elemen-elemen yang ada pada klaster SDM KJKS, ketiga pihak responden memiliki penilaian yang berbeda mengenai prioritas. Pihak akademisi menilai bahwa elemen Partisipasi Anggota adalah prioritas yaitu sebesar 23,8\% karena anggota merupakan captive market atau sasaran utama untuk berwakaf tunai. Harapan potensi wakaf uang dapat terkumpul banyak di KJKS adalah berasal dari anggota.

Sedangkan pihak regulator menilai justru elemen Kemampuan Manajerial merupakan elemen prioritas dalam pengelolaan wakaf uang pada KJKS dengan nilai sebesar 22,6\%, pertimbangan penilaian prioritas pada elemen tersebut adalah karena dengan kemampuan manajerial yang baik maka anggota ataupun masyarakat akan dapat dengan mudah digerakan untuk berwakaf uang selain itu juga pengelolaan wakaf uang di KJKS tentu akan lebih baik dan optimal.

Lain halnya dengan praktisi yang menganggap bahwa pemimpin visioner merupakan elemen yang paling penting yaitu sebesar $20,5 \%$, karena sosok pemimpin yang mampu membawa cita-cita lembaga yang dipimpin serta arahan yang baik tentu akan memberikan efek yang baik bagi setiap aktivitas di dalamnya termasuk pengelolaan wakaf uang. Untuk lebih jelasnya, uraian mengenai prioritas pada Klaster SDM KJKS dapat dilihat pada Gambar 4. 


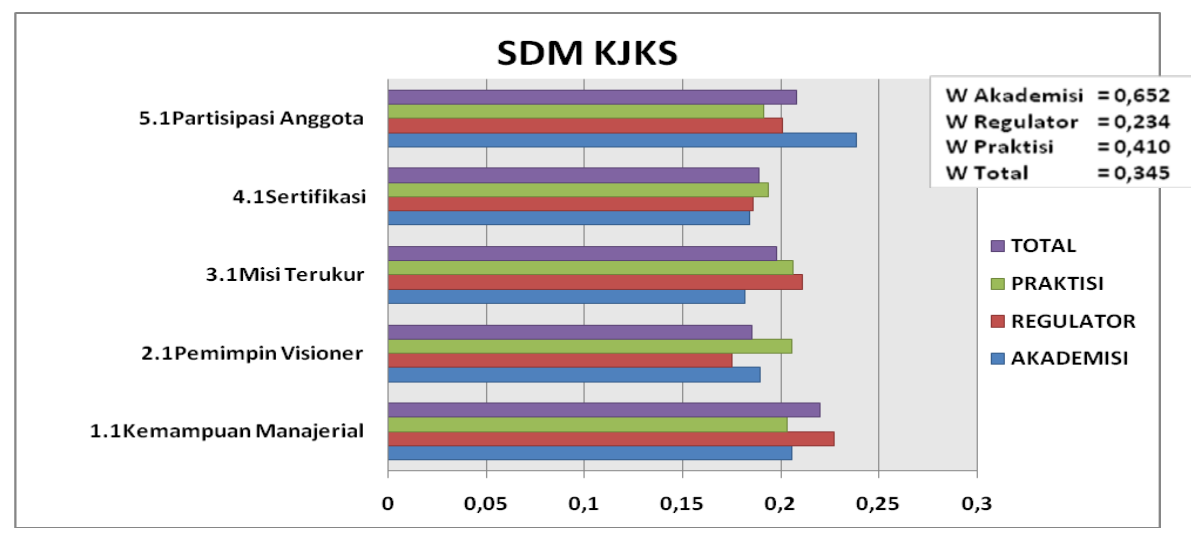

\section{Gambar 4 Prioritas Klaster SDM KJKS}

Kesesuaian penilaian responden mengenai SDM KJKS dapat dilihat pada nilai W. Secara keseluruhan nilai $\mathrm{W}$ total sebesar 0,345 . Nilai tersebut tergolong rendah, artinya penilaian responden terkait SDM KJKS bervariasi.

Selanjutnya adalah penilaian pada klaster Akuntabilitas. Untuk lebih jelas dapat dilihat pada Gambar 5. Uraian mengenai penilaiannya, pertama pihak regulator dan pihak praktisi menilai bahwa elemen prioritas dalam pengelolaan wakaf uang adalah Jumlah Asset, meskipun dengan bobot nilai yang berbeda namun pada tempatnya masing-masing menduduki penilaian prioritas yaitu sebesar $23,5 \%$ dan $21,8 \%$. Menurut keduanya elemen Jumlah Asset dinilai penting karena merupakan poin yang dapat memberikan gambaran kondisi sebuah lembaga keuangan. Selain itu Jumlah Asset juga dianggap berbanding lurus dengan kepercayaan masyarakat, lembaga keuangan yang memiliki asset besar tentu mendapat kepercayaan lebih karena mampu mengelola dana masyarakat dalam jumlah besar. Maka dari itu KJKS yang memiliki asset besar juga akan dinilai mampu untuk mengelola wakaf uang.

Lain halnya dengan pihak akademisi yang memberikan penilaian bahwa elemen Penunjang Fasilitas IT merupakan elemen prioritas dengan nilai sebesar 22,5\%, dengan adanya teknologi yang memadai tentu akan menunjang transparansi pengelolaan dana anggota dan masyarakat selain itu informasi akan mudah tersampaikan sehingga kepercayaan mereka kepada lembaga dapat dijaga.

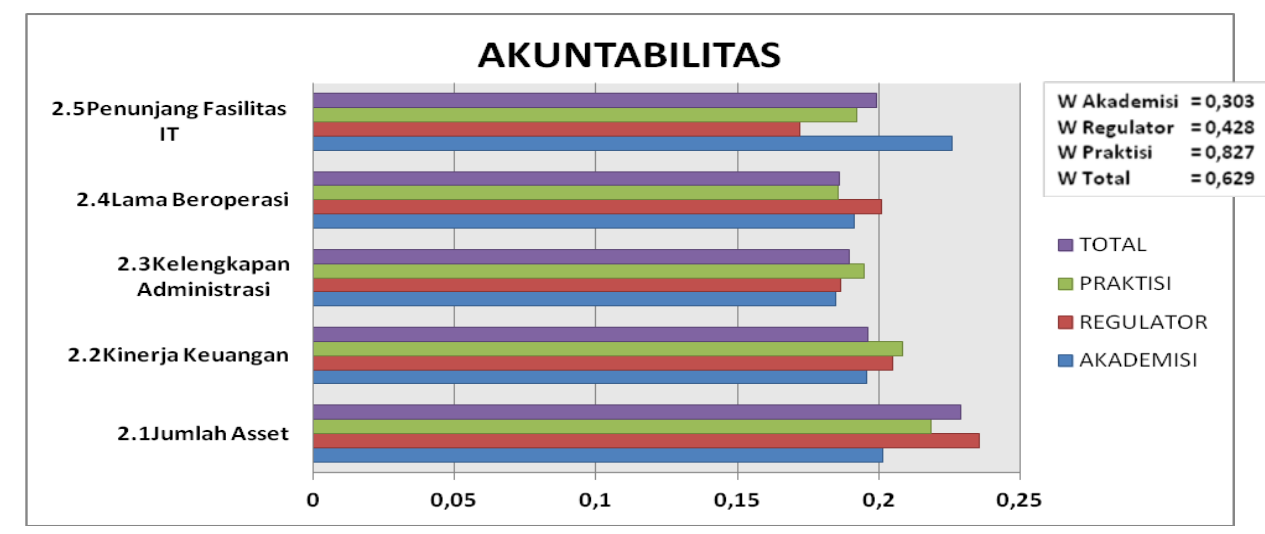

Gambar 5 Prioritas Klaster Akuntabilitas 
Nilai kesesuaian untuk klaster Akuntabilitas secara total adalah senilai 0,629. Nilai tersebut tergolong tinggi dan juga artinya adalah penilaian seluruh responden untuk klaster Akuntabilitas tidak bervariasi.

Poin terkahir dalam Aspek Internal adalah Klaster Produk. Produk yang dimaksud adalah tentang bagaimana konsep wakaf uang dapat diperkenalkan ke masyarakat dan anggota supaya dengan mudah mereka mengetahui dan tertarik untuk berwakaf uang di KJKS. Pihak Akademisi dan Regulator memiliki pendapat yang sama yaitu elemen prioritas adalah Edukasi Masyarakat dengan nilai masing-masing sebesar 22,1\% dan 22,9\%. Menurut mereka pemahaman mengenai wakaf uang harus terus dilakukan kepada anggota maupun masyarakat umum. Sedangkan pihak praktisi berpendapat bahwa elemen Media Sosialisasi adalah prioritas karena dengan itu akan memudahkan tugas nazhir mensosialisasikan dan memperkenalkan wakaf uang serta ajakan untuk anggota dan masyarakat berwakaf uang bisa lebih cepat tersampaikan. Untuk lebih jelasnya, penilaian untuk klaster Produk dapat dilihat pada Gambar 6.

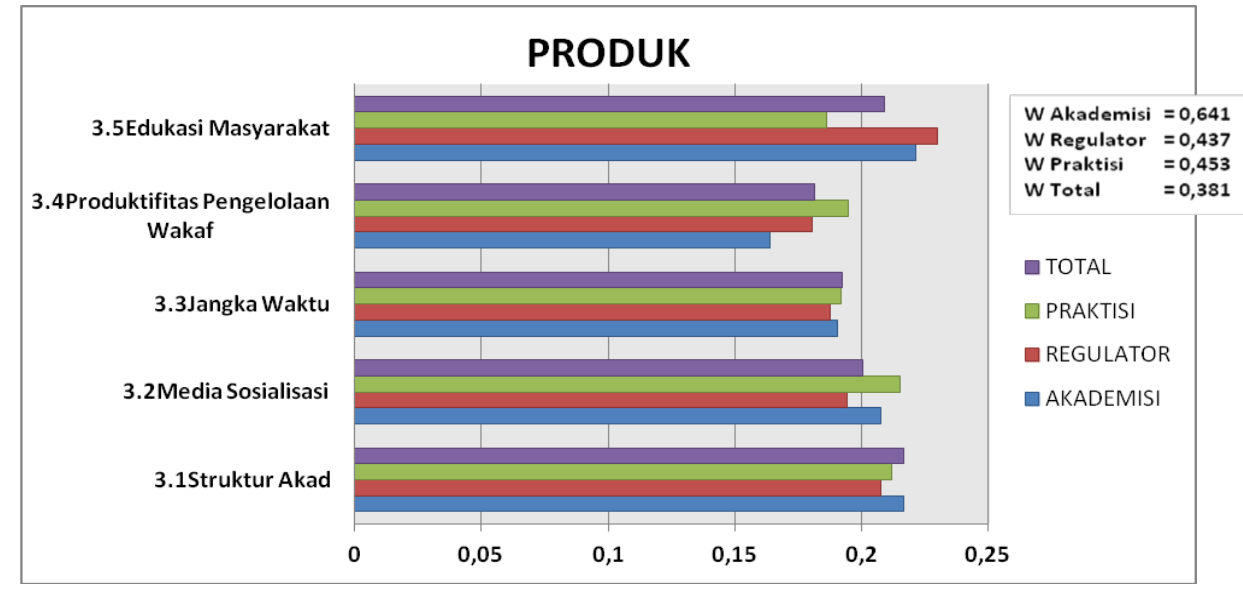

Gambar 6 Prioritas Klaster Produk

Namun secara keseluruhan hasil penilaian geomean seluruh pihak responden didapatkan hasil bahwa prioritas total adalah pada elemen Struktur Akad. Adapun nilai kesesuaian untuk penilaian klaster Produk secara total adalah sebesar 0,381. Nilai tersebut tergolong rendah karena seluruh responden memberikan penilaian yang bervariasi terhadap masingmasing elemen pada klaster Produk.

Pada Gambar 7 dipaparkan uraian secara keseluruhan mengenai penilaian responden terhadap klaster-klaster pada Aspek Internal. Responden berpendapat bahwa elemen prioritas terkait pengelolaan wakaf di KJKS adalah elemen Jumlah Asset (22,8\%). Jumlah Asset merupakan elemen dari klaster Akuntabilitas. Sesuai dengan hasil penilaian yang diperoleh sebelumnya dari klaster umum yaitu prioritas aspek internal adalah Klaster Akuntabilitas dan secara lebih rinci elemen yang menjadi prioritas adalah elemen Jumlah Asset.

Besarnya jumlah asset pada KJKS menjadikan tolak ukur kapabilitas sebuah KJKS dalam mengelola dana anggotanya. Makin besar jumlah asset yang dimiliki oleh KJKS akan memberikan kepercayaan pada KJKS itu sendiri bahwa KJKS tersebut mampu mengelola dana masyarakat. Terkait hal tersebut tentu saja akan memberikan kepercayaan juga bagi masyarakat untuk berwakaf uang di KJKS. 


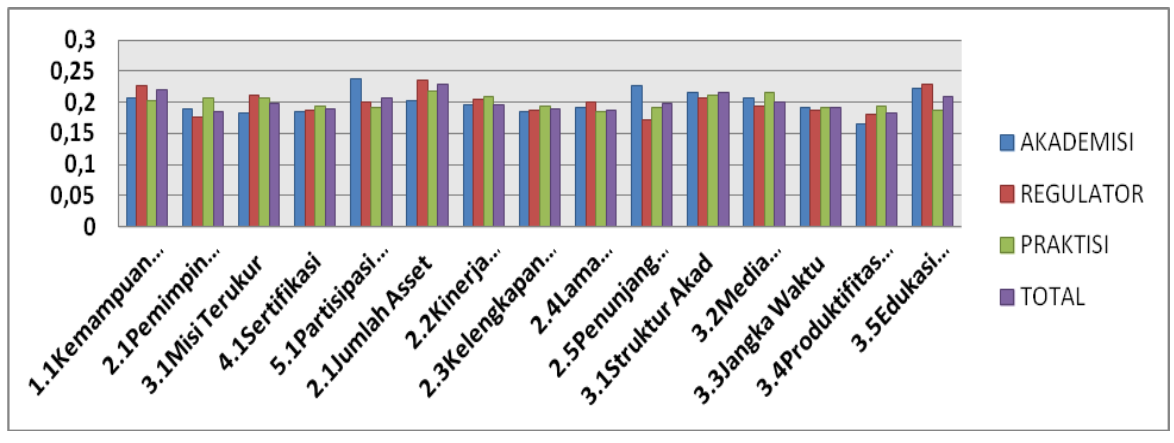

Gambar 7 Uraian Prioritas Aspek Internal

Selanjutnya penilaian pada klaster Aspek Eksternal. Pertama adalah uraian penilaian pada klaster Regulasi. Secara lebih rinci dapat dilihat pada Gambar 8.

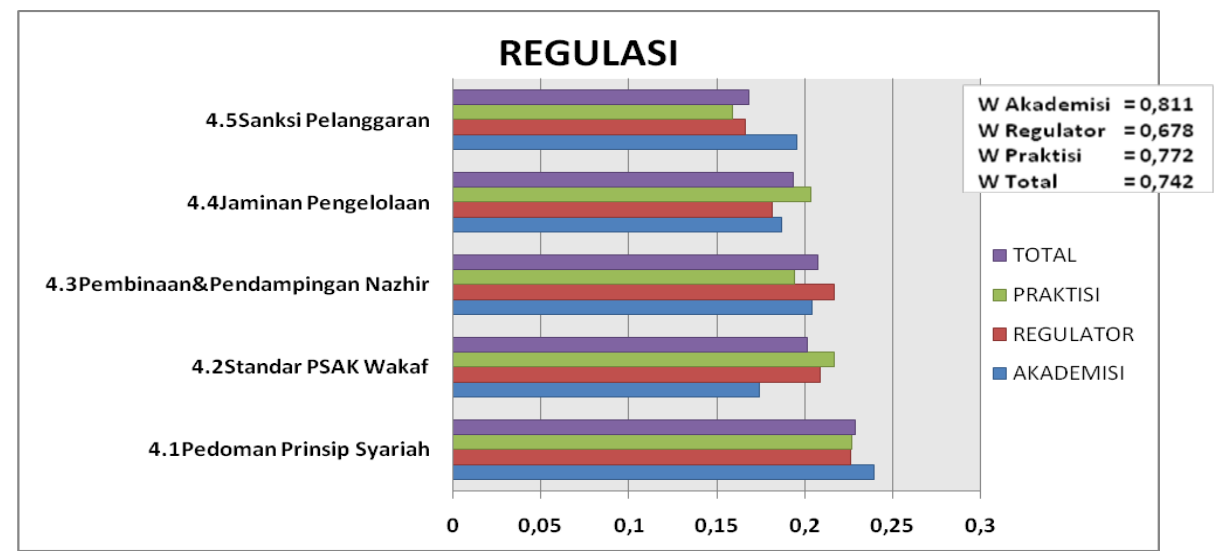

\section{Gambar 8 Prioritas Klaster Regulasi}

Dari Gambar 8 dapat dijelaskan bahwa ketiga responden sepakat bahwa prioritas adalah pada elemen Pedoman Prinsip Syariah dengan nilai masing-masing 23,9\% (akademisi) $22,6 \%$ (praktisi) dan 22,6\% (regulator). Kesamaan pendapat tersebut menegaskan bahwa yang membedakan koperasi syariah dengan selainnya adalah pada struktur kepengurusan yaitu Dewan Pengawas Syariah sehingga setiap aktivitasnya harus selalu diawasi agar tidak melanggar atau bertentangan dengan syariah.

Secara keseluruhan pun hasilnya sama yaitu dari penghitungan geomean juga didapatkan hasil bahwa prioritas elemen dalam pengelolaan wakaf uang pada KJKS adalah elemen Pedoman Prinsip Syariah. Kesesuaian pendapat seluruh responden dapat dilihat dari nilai W total yaitu sebesar 0,742. Nilai tersebut tergolong tinggi dikarenakan seluruh responden memberikan penilaian yang tidak bervariasi.

Berikutnya yang kedua adalah penilaian klaster Demografi, pihak akademisi menilai Budaya Setempat merupakan elemen paling penting (22\%), karena wakaf ini merupakan kegiatan yang berkaitan dengan sosial sehingga kebiasaan setempat juga dinilai berpengaruh. Pihak regulator menganggap Jumlah Penduduk yang merupakan elemen penting $(20,8 \%)$ karena diharapkan jumlah penduduk berbanding lurus dengan perolehan wakaf uang. Sedangkan praktisi menganggap Profesi merupakan prioritas (21\%) karena jenis profesi berpengaruh terhadap jumlah pendapatan seseorang. 


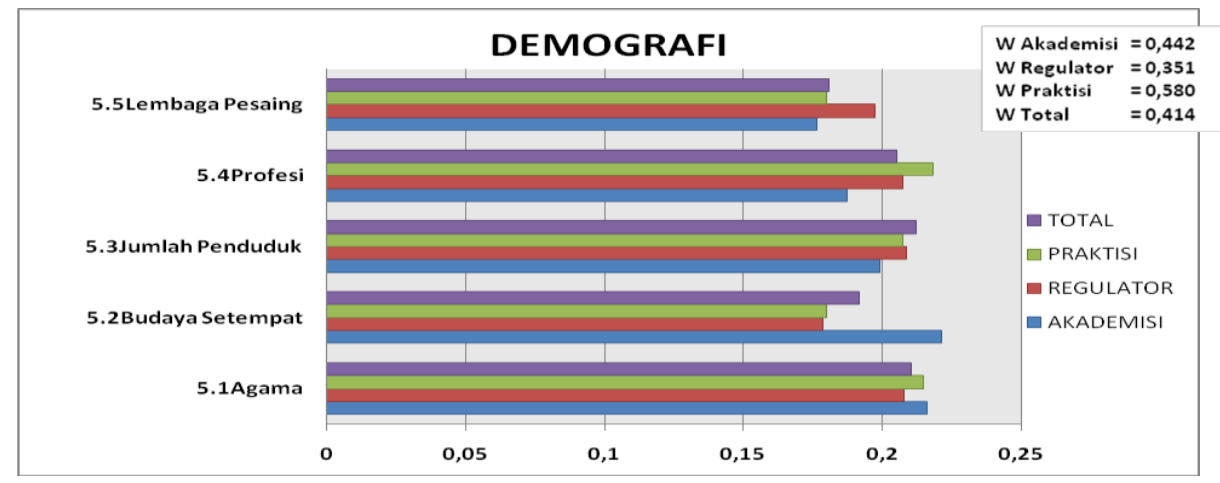

\section{Gambar 8 Prioritas Klaster Demografi}

Nilai kesesuaian pada klaster Demografi secara keseluruhan adalah sebesar 0,414. Nilai tersebut tergolong rendah artinya seluruh responden memberikan penilaian yang bervariasi.

Ketiga, penilaiaan klaster Masyarakat Umum. Regulator dan praktisi berpendapat sama bahwa Inisiatif Pemilik Harta merupakan elemen prioritas karena merupakan kesadaran dari dalam pribadi seseorang untuk berwakaf. Dengan adanya kesadaran sendiri tentu akan lebih mudah lagi bagi KJKS untuk menghimpun wakaf uang dari masyarakat. Masing-masing dengan nilai 22\% dan 20\%. Sedangkan pihak akademisi menilai bahwa yang paling penting dari penilaian Masyarakat Umum adalah pada Tingkat Keyakinan Keberhasilan terhadap wakaf itu sendiri (22\%). Uraian dari hasil penilaian klaster Masyarakat Umum dapat dilihat pada Gambar 9.

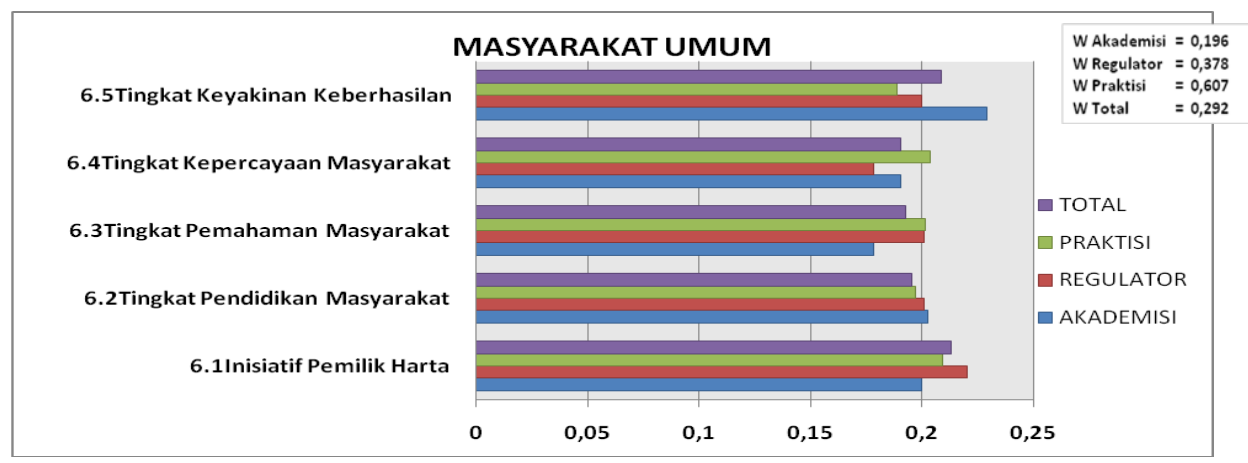

\section{Gambar 9 Prioritas Klaster Masyarakat Umum}

Hasil dari total penilaian seluruh responden menunjukan bahwa prioritas pada klaster Masyarakat Umum adalah elemen Inisiatif Pemilik Harta. Nilai kesesuaian total adalah sebesar 0,292 . Artinya tergolong rendah karena seluruh responden memberikan pendapat yang bervariasi dalam penilaian.

Poin terakhir adalah penjelasan mengenai uraian secara keseluruhan pada Aspek Eksternal. Penjelasan diuraikan pada Gambar 10. Secara keseluruhan responden berpendapat bahwa hal yang paling penting dalam pengelolaan wakaf uang adalah Pedoman Prinsip Syariah (22,9\%). 


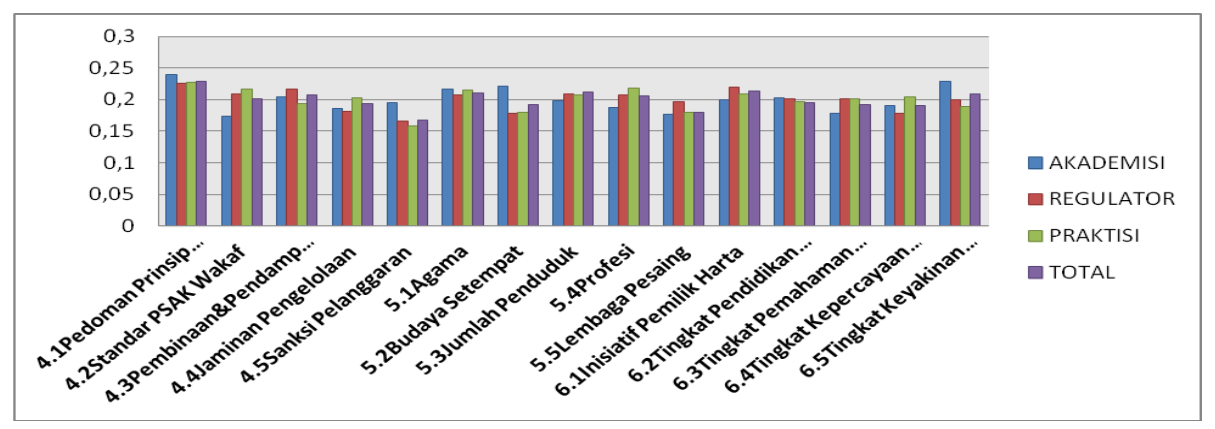

Gambar 10 Uraian Aspek Eksternal

\section{Kesimpulan dan Saran}

\subsection{Kesimpulan}

Dari hasil penjelasan di atas, poin yang dapat peneliti simpulkan adalah:

1. Pengelolaan wakaf uang di KJKS melibatkan 3 pihak yaitu Kementerian Koperasi\&UKM lebih spesifik lagi yaitu Deputi Pembiayaan Syariah, Badan Wakaf Indonesia (BWI), dan Koperasi Jasa Keuangan Syariah (KJKS). Dalam hal ini yang berperan sebagai nazhir adalah KJKS.

2. Prioritas faktor-faktor strategis dalam pengelolaan wakaf uang secara berurutan dari sisi internal adalah Akuntabilitas, Produk, dan SDM KJKS. Dari sisi eksternal adalah Regulasi, Masyarakat Umum, dan Demografi. Secara detail, prioritas utama adalah pada elemen Jumlah Asset dan Pedoman Prinsip Syariah.

\subsection{Saran}

Penelitian ini merupakan penelitian awal yang berusaha menganalisis pengelolaan wakaf uang di KJKS yang disandarkan hanya pada aspek internal dan aspek eksternal saja. Adapun saran yang dapat diberikan adalah sebagai berikut:

1. Bagi KJKS yang belum terdaftar sebagai nazhir wakaf uang diharapkan dapat mempersiapkan lembaganya supaya dinilai mampu menjadi nazhir wakaf uang. Adapun kedepannya KJKS yang sudah menjadi nazhir wakaf uang diharapkan mampu melakukan beberapa hal yaitu: Penjagaan akuntabilitas lembaga dengan memberikan laporan pengelolaan wakaf uang secara tepat waktu, Penguatan SDM dengan cara memberikan pelatihan peningkatan kemampuan menajerial khususnya mengenai wakaf secara berkala, Menjaga prinsip syariah dengan rutin mengadakan forum diskusi dengan DPS, edukasi mengenai wakaf uang yang terus menerus dilakukan kepada masyarakat.

2. Berikutnya dapat dilakukan penelitian mengenai wakaf uang secara lebih mendalam untuk dapat mengembangkan temuan yang ada pada pada penelitian ini. Beberapa hal yang perlu dijadikan objek penelitian diantaranya mengenai manajemen resiko pengelolaan wakaf uang di KJKS, alternatif penyusunan ataupun perumusan standar PSAK wakaf supaya lembaga wakaf lebih akuntabel, serta isu mengenai pencatatan akta wakaf di KJKS.

\section{Daftar Pustaka}

Ascarya. 2005. The Lack of Profit-and-Loss Sharing Financing in Indonesia's Islamic Banks Using ANP: Revisited. Center of Education and Central Banking Studies. Bank Indonesia. 
Ascarya, 2015. Paper presented at Inaugural Annual Symposium on Islamic Finance 2015 "Islamic Finance: A Catalyst for Shared Prosperity", Istanbul, Turkey, September 89, 2015.

Buchori SN. 2010. Koperasi dalam Perspektif Ekonomi Syari’ah. Jurnal Maslahah. 1(1):93-115.

Hidayat K. Suharyono. Kumadji S. Solimun. 2014. The Effect of Members Participation on Business Self-Reliance and Members Welfare (Study on Cooperative Corporation in East Java Indonesia). Journal of Business and Management (IOSR-JBM). 16(1):15-21.

Kahf M. 2007. Wakaf Islam (Sejarah, Pengelolaan, dan Pengembangannya). Jakarta (ID): Badan Wakaf Indonesia.

Kementerian Koperasi dan UKM. Program dan Kegiatan Strategis Deputi Bidang Pembiayaan (Paparan Deputi Bidang Pembiayaan Dalam Rapat Koordinasi Nasional Kementerian Koperasi dan UKM Tahun 2013).

Maskunah. 2004. Analisis Hubungan Antara Kepuasan Kerja, Struktur Organisasi Dan Lingkungan Khusus Koperasi Terhadap Kinerja Koperasi [Tesis]. Bogor (ID): Intitut Pertanian Bogor.

Mu'allim M. 2014. Peningkatkan Wakaf Uang (Tunai) Sebagai Upaya Peningkatkan Kesejahteraan Masyarakat. Jurnal Bimas Islam. 7(IV): 727-754.

Mustofa A, Mursinto D, Anam S. 2014. Influence of The Islamic Leadership To Participation Of The Members, Business Performance And Prosperity Of The Members Of Syari'ah Financial Service Cooperative In East Kalimantan Province. European Journal of Business and Management. 6(38):217-226.

Nafis CHM. 2010. Peluang Kemitraan Investasi Wakaf Produktif. [Internet]. [Diunduh 17 Januari 2015] tersedia pada www.bwi.or.id

Pristiyanto. 2013. Strategi Pengembangan Koperasi Jasa Keuangan Syariah Dalam Pembiayaan Usaha Mikro di Kecamatan Tanjungsari, Sumedang. Jurnal Manajemen IKM. 8(1):27-35.

Ridwan M. 2004. Manajemen Baitul Maal wa Tamwil (BMT). Yogyakarta (ID): UII Pr.

Rusdiyan A. 2012. Analytic Network Process: Metodologi Powerfull Untuk Problem Manajemen. [Internet]. [Diunduh 16 Agustus 2015] tersedia pada http://www.konsultan-anp.com

Sinaga P. 2011. Koperasi Jasa Keuangan Syariah Terus Tumbuh [Internet]. Jakarta (ID); [Diunduh 12 November 2014]. Tersedia pada:

http://female.kompas.com/read/2011/11/12/12521386/Koperasi.Jasa.Keuangan.Syari ah.Terus.Tumbuh

Saaty TL. 2006. Fundamentals of the Analytic Network Process. [Internet]. [Diunduh 16 Agustus 2015]. Tersedia pada: http://www.researchgate.net/publication/228578822

Syafrudin A. 2010. Wakaf Tunai sebagai Alternatif Mekanisme Redistribusi Keuangan Islam. Jurnal Ekonomi Islam La Riba. 1(1):85-115.

Tambunan T. 2008. Prospek Perkembangan Koperasi di Indonesia ke depan: Masih Relevankah Koperasi di dalam Era Modernisasi Ekonomi?. Pusat Studi Industri dan UKM Universitas Trisakti

Tanjung H, Devi A. 2013. Metodologi Penelitian Ekonomi Islam. Bekasi (ID): Gramatika Publishing. 